\title{
Eicosapentaenoic acid increases lipolysis through up-regulation of the lipolytic gene expression and down-regulation of the adipogenic gene expression in 3T3-L1 adipocytes
}

\author{
Mak-Soon Lee · In-Sook Kwun · Yangha Kim
}

Published online: 17 November 2007

(C) Springer-Verlag 2007

\begin{abstract}
In this study, we investigated the lipolytic effects of eicosapentaenoic acid (EPA) in 3T3-L1 adipocytes. The differentiated 3T3-L1 adipocytes were treated in a serum-free medium with $300 \mu \mathrm{M}$ of EPA for 3, 6, 12, and $24 \mathrm{~h}$. In comparison with the control, intracellular lipid accumulation was significantly decreased by $24 \%$ at $24 \mathrm{~h}$ following the addition of EPA $(P<0.05)$. Under the same experimental conditions, there was an increase of glycerol and free fatty acids (FFAs). The mRNA level of carnitine palmitoyltransferase I-a, a component of the fatty-acid shuttle system involved in the mitochondrial oxidation of long-chain fatty acids, was also significantly elevated by EPA $(P<0.05)$. However, the expression of peroxisome proliferator-activated receptor- $\gamma$ and acetyl-CoA carboxylase (ACC), which are involved in adipogenesis, was significantly down-regulated by EPA $(P<0.05)$. These results suggest that EPA may modulate lipid metabolism by stimulation of lipolysis, which was associated with induction of lipolytic gene expression and suppression of adipogenic gene expression in 3T3-L1 adipocytes.
\end{abstract}

Keywords Acetyl-CoA carboxylase - 3T3-adipocytes . Carnitine palmitoyltransferase I- $\alpha \cdot$ EPA $\cdot$ Free fatty acid . Glycerol - Peroxisome proliferator-activated receptor- $\gamma$. Lipolysis · Gene expression

M.-S. Lee · Y. Kim ( $₫)$

Department of Food and Nutritional Sciences, Ewha Womans University, Daehyun-Dong 11-1, Sudaemun-Gu,

Seoul 120-750, Republic of Korea

e-mail: yhmoon@ewha.ac.kr

I.-S. Kwun

Department of Food Science and Nutrition, Andong National University, Andong 760-749, Republic of Korea

\section{Introduction}

Adipose tissue stores energy in the form of lipids and releases fatty acids in response to nutritional signals or energy insufficiencies [1]. Excessive fat accumulation in the white adipose tissue causes obesity and leads to in an increased risk of various disorders, such as type II diabetes, hypertension and coronary heart disease [2, 3]. Consequently, there has been considerable interest in the role of dietary fat in the development of adiposity. Compared to lard or corn oil-fed groups, total body fat or abdominal fat mass were considerably reduced in rodents fed with fish oil or perilla oil containing plenty of $n-3$ polyunsaturated fatty acids (PUFA) [4, 5]. The polyunsaturated fatty acids, especially those in the class of n-3 fatty acids, are now known to affect all four of the metabolic nuclear receptors that modulate triglyceride (TG) levels. These include liver $\times$ receptor $(\mathrm{L} \times \mathrm{R})$, farnesoid $\times$ receptor $(\mathrm{F} \times \mathrm{R})$, and hepatocyte nuclear factor- $4 \alpha$ (HNF- $4 \alpha)$, and peroxisome proliferator-activated receptors (PPARs) controlling the expression of genes involved in lipid and glucose metabolism [6, 7]. However, the direct effect of n-3 fatty acids on lipolysis in vitro remains largely unresolved.

In the present study, we investigated the effects of eicosapentaenoic acid (EPA), known as one of the most critical components of n-3 PUFA, on lipid metabolism and the underlying mechanisms in 3T3-L1 adipocytes. We hypothesize that EPA stimulates lipolysis through induction of lipolytic gene expression and suppression of adipogenic gene expression. We measured the lipid accumulation and release of free fatty acids (FFAs) and glycerol into medium followed by EPA treatment. In addition, the mRNA levels of the adipogenic genes including peroxisome proliferator-activated receptor- $\gamma$ (PPAR- $\gamma$ ) and acetyl-CoA carboxylase (ACC), and carnitine 
palmitoyltransferase I-a (CPT-I $\alpha)$, one of lipolytic genes, were measured.

\section{Materials and methods}

Materials

EPA (Sigma, St. Louis, MO; purity >99\%) was dissolved in ethanol and stored in the dark as stock solution at $-20^{\circ} \mathrm{C}$. The EPA were freshly prepared from the stock solution and diluted with growth medium. An acyl-CoA oxidase-based colorimetric kit (NEFA-C) was obtained from Wako (Tokyo, Japan), and a BCA protein assay kit was obtained from Pierce (Rockford, USA). The 3T3-L1 cell line was obtained from American Type Culture Collection (Manassas, VA).

\section{Cell culture}

3T3-L1 fibroblasts were initially maintained in Dulbecco's modified Eagle's medium (DMEM) supplemented with $10 \%$ fetal bovine serum, $2 \mathrm{mM} / 1$ glutamine, $100 \mathrm{U} / 1$ penicillin, and $100 \mu \mathrm{g} / \mathrm{ml}$ streptomycin in a humidified atmosphere of $95 \%$ air $/ 5 \% \mathrm{CO}_{2}$ at $37^{\circ} \mathrm{C}$. To induce adipocytic differentiation, 3T3-L1 cells were allowed to grow to confluence and cultured with differentiation medium containing $\quad 0.5 \mathrm{mM} / 1$ isobutylmethylxanthine, $1 \mu \mathrm{M} / \mathrm{l}$ dexamethasone, and $5 \mu \mathrm{g} / \mathrm{ml}$ insulin. After $48 \mathrm{~h}$ exposure to the differentiation medium, cells were maintained for an additional 5-7 days in Dulbecco's modified Eagle's medium supplemented with $10 \%$ fetal bovine serum. Cells were then treated with $300 \mu \mathrm{M} / 1$ of EPA for 3, 6, 12, or $24 \mathrm{~h}$ in serum-free media.

\section{Oil Red O staining}

The 3T3-L1 adipocytes were washed with phosphate-buffered saline ( $\mathrm{pH} 7.4)$ and then fixed with $10 \%$ formalin in phosphate-buffered saline. Cells were stained with Oil Red $\mathrm{O}$ dye (saturated Oil Red $\mathrm{O}$ dye in six parts of isopropanol and four parts of water). Spectrophotometric quantification of the stain was performed by dissolving the stained oil droplets in the cell monolayer with $4 \%$ Nonidet P-40 in isopropanol and measuring absorbance at $520 \mathrm{~nm}$ [8]. The values were calculated as percentages of the control cells treated without EPA and expressed as the mean $\pm \mathrm{SD}$.

\section{Lipolysis assays}

The amounts of glycerol and FFA released from cells into the medium were measured to analyze the lipolytic effect of EPA on the accumulated triacylglycerol in adipocytes. Medium was collected from the culture plate and heated at $65^{\circ} \mathrm{C}$ for $8 \mathrm{~min}$ to inactivate any enzymes released from the cells. The amounts of glycerol and FFA were measured by using a commercial glycerol analysis kit (Roche) and an ACO-based colorimetric kit (Wako), respectively. Cellular protein content was analyzed using a BCA protein assay kit (Pierce). Data were expressed as the mean \pm SD.

Quantitative real-time reverse transcription-polymerase chain reaction $(\mathrm{PCR})$

Total RNA was extracted from 3T3-L1 adipocytes using TRIzol ${ }^{\circledR}$ Reagent (Promega, Madison, WI). The cDNAs were synthesized from $5 \mu \mathrm{g}$ of RNA using M-MLV reverse transcriptase (Promega). After cDNA synthesis, quantitative real-time PCR was performed in $25 \mu$ l of Universal SYBR Green PCR Master Mix (Qiagen, Chatsworth, CA) using a fluorometric thermal cycler (Rotor-Gene ${ }^{\mathrm{TM}} 2000$; Corbett Research, Mortlake, NSW, Australia). Reaction mixtures were incubated for an initial denaturation at $95^{\circ} \mathrm{C}$ for $10 \mathrm{~min}$, followed by $50 \mathrm{PCR}$ cycles. Each cycle consisted of $95^{\circ} \mathrm{C}$ for $10 \mathrm{~s}, 55^{\circ} \mathrm{C}$ for $20 \mathrm{~s}$, and $72^{\circ} \mathrm{C}$ for $20 \mathrm{~s}$. Primers were designed using an on-line program (primer3 http://www.cgivo.2) [9]. The sequences of the sense and antisense primers used for amplification were as follows: PPAR $\gamma, 5^{\prime}$-TTGATTTCTCCAGCATTTCT- $3^{\prime}$ and $5^{\prime}$-TG TTGTAGAGCTGGGTCTTT-3'; ACC,$\quad 5^{\prime}$-CTGTGAG TGGATCAGAGAT- $3^{\prime}$ and 5'-TTCAGCTCTAACTGGA AAGC-3'; CPT-I $\alpha, 5^{\prime}$-GTGTT GGAGGTG ACAGACTT$3^{\prime}$ and $5^{\prime}$-CACTTTCTCTTTCCACAAGG- $3^{\prime} ; \quad \beta$-actin, $5^{\prime}$-GTTGCCAATAGTGATGACCT-3' and $5^{\prime}$-GGACCT GACAGACTACCTCA-3'. The $\Delta C_{\mathrm{T}}$ method was used to measure relative quantification. Values were expressed as fold change over control and expressed as the mean \pm SD.

Statistical analysis

The results are expressed as mean \pm SD. The statistical significance of differences between groups was determined by the Student's $t$-test (two-tailed) using the SPSS package program version 11.0 (SPSS, Chicago, IL). Also, the significant differences among groups were determined by oneway analysis of variance. The results were considered to be significant if the value of $P$ was $<0.05$, and Tukey's multiple range test was performed if differences were identified between groups at $\alpha=0.05$.

\section{Results and discussion}

The differentiated 3T3-L1 adipocytes were treated in a serum-free medium with $300 \mu \mathrm{M} / 1$ of EPA for 3, 6, 12, and 
Table 1 Inhibitory effects of EPA on lipid accumulation in 3T3-L1 adipocytes

\begin{tabular}{lll}
\hline Treatment $(\mathrm{h})$ & \multicolumn{2}{l}{ Lipid accumulation $(\%)$} \\
\cline { 2 - 3 } & Control & EPA \\
\hline 0 & $100.0 \pm 9.9^{\mathrm{a}}$ & $100.0 \pm 9.6^{\mathrm{a}}$ \\
3 & $98.3 \pm 6.3^{\mathrm{a}, \mathrm{b}}$ & $89.4 \pm 2 .^{\mathrm{a}, \mathrm{b}}$ \\
6 & $93.8 \pm 9.5^{\mathrm{a}, \mathrm{b}}$ & $88.1 \pm 1.1^{\mathrm{a}, \mathrm{b}}$ \\
12 & $94.5 \pm 9.6^{\mathrm{a}, \mathrm{b}}$ & $83.1 \pm 12.5^{\mathrm{a}, \mathrm{b}}$ \\
24 & $93.8 \pm 5.0^{\mathrm{a}, \mathrm{b}}$ & $76.0 \pm 2.9^{\mathrm{b}}$ \\
\hline
\end{tabular}

The 3T3-L1 adipocytes were incubated in serum-free medium with $300 \mu \mathrm{M}$ of EPA for $3,6,12$, or $24 \mathrm{~h}$. The values were calculated as a percentage of lipid content of the control cells without EPA treatment and expressed as the mean $\pm \mathrm{SD}(n=5)$. Values with different superscript letters are significantly different at $P<0.05$ by Tukey's test

24 h. The intracellular oil droplets were stained with Oil Red O dye and quantified. In comparison with the control, lipid accumulation was significantly decreased by $24 \%$ at $24 \mathrm{~h}$ following the addition of EPA, but had no effect during early stages 3 to $12 \mathrm{~h}$ of the experiment (Table 1). The amounts of glycerol released into the medium was notably increased by $61 \%$ at $24 \mathrm{~h}$ following the addition of EPA, but had no effect during the early stages 3 to $12 \mathrm{~h}$ of the experiment (Fig. 1a). Additionally, the amounts of FFA in the medium were increased compared to the control by
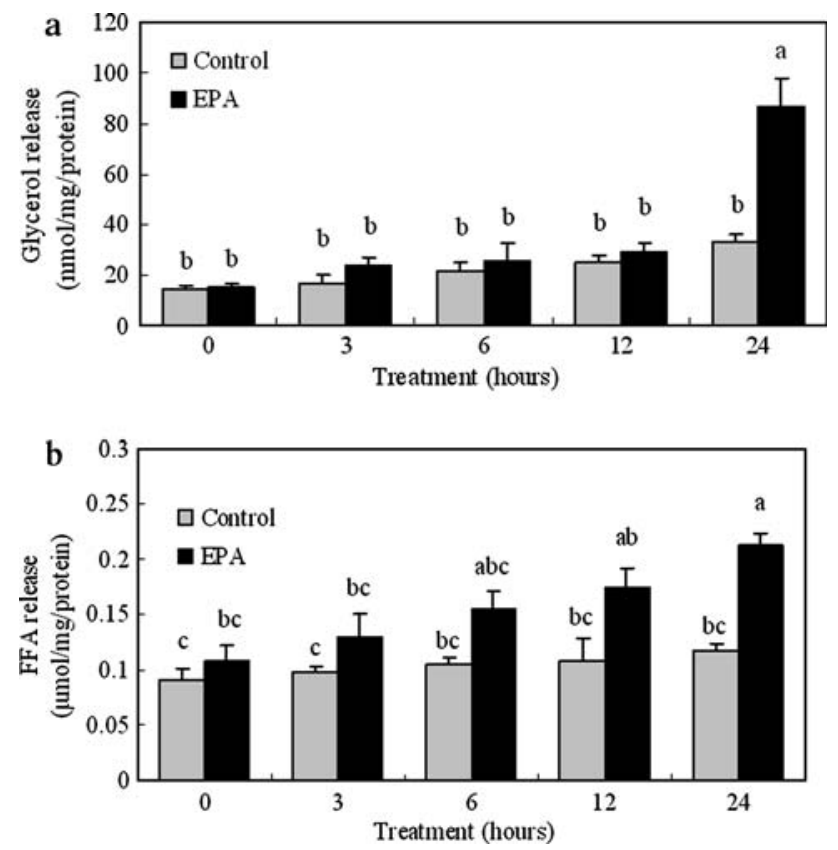

Fig. 1 Time course of EPA-induced lipolysis in 3T3-L1 adipocytes. The 3T3-L1 adipocytes were treated in serum-free medium with $300 \mu \mathrm{M} / 1$ of EPA for 3, 6, 12, or $24 \mathrm{~h}$ The medium was collected and assayed for glycerol (a) and FFA content (b). Data are mean \pm SD values $(n=5)$. Values with different superscript letters are significantly different at $P<0.05$ by Tukey's test

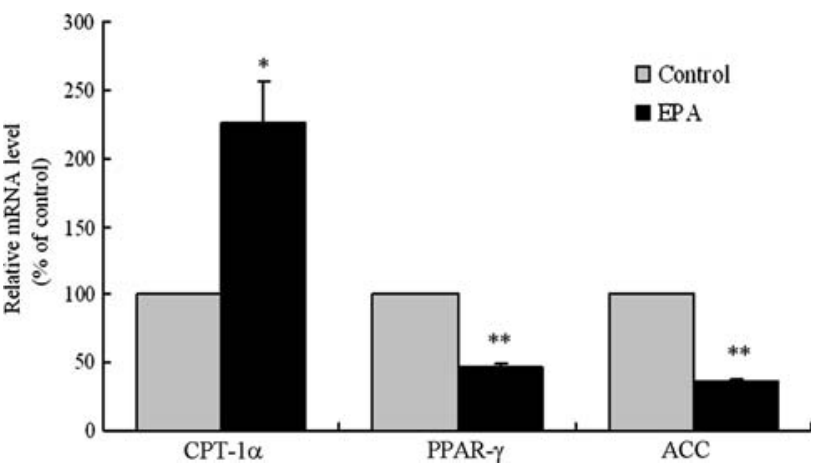

Fig. 2 Effect of EPA on the mRNA levels of CPT1- $\alpha$, PPAR- $\gamma$, and ACC. The 3T3-L1 adipocytes were incubated for $24 \mathrm{~h}$ in serum-free medium with or without $300 \mu \mathrm{M}$ of EPA. The amounts of mRNA were measured by quantitative real-time PCR. Data are mean $\pm \mathrm{SD}$ values $(n=9) .{ }^{*} P<0.05$ and ${ }^{* *} P<0.01$ versus control (no treatment)

38.5 and $44.6 \%$ at 12 and $24 \mathrm{~h}$, respectively (Fig. 1b). These results led to the conclusion that EPA stimulated lipolysis in adipocytes as evidenced by the decreased lipid content in cells and the increased concentrations of glycerol and FFA in the medium. Lending further support to our findings, other investigators reported that the plasma TG levels were decreased in animals given n-3 PUFA diet, compared with the control diet $[10,11]$, in order to investigate the underlying mechanisms of inhibitory effects of EPA on lipid accumulation, the mRNA levels of the lipolytic gene, such as CPT-I $\alpha$ (and adipogenic genes such as PPAR- $\gamma$ and ACC were analyzed by real-time PCR). CPT-I $\alpha$, which is located on the outer mitochondrial membrane, is the rate-limiting enzyme for fatty acid oxidation. Following the activation of fatty acids to produce acyl-CoA thioesters, CPT-I $\alpha$ catalyzes the transfer of acyl groups from acyl-CoA to carnitine, producing acylcarnitine. This reaction is the initial step in the transport of longchain fatty acids from the cytosol into the mitochondrial matrix for fatty acid oxidation $[12,13]$. In this study, the mRNA level of CPT-I $\alpha$ was significantly increased by 2.3fold compared to the control $(P<0.05)$ following EPA supplementation (Fig. 2). This finding strongly indicats that EPA may promote CPT-Ia gene expression for mitochondrial fatty acid $\beta$-oxidation. PPAR- $\gamma$ is the adipocytespecific transcription factor that appears to promote adipocyte differentiation and control the expression of several fat-specific genes [14, 15]. ACC is known as the ratelimiting enzyme in the de novo synthesis of fatty acids $[16,17]$. In our study, the mRNA level of PPAR- $\gamma$ was found to be decreased after EPA supplementation by $53.4 \%$ compared to the control $(P<0.05)$. In addition, the mRNA level of ACC was decreased by $63.7 \%$ (Fig. 2). These results imply that EPA attenuates lipid accumulation in adipocytes, possibly via down-regulation of PPAR- $\gamma$ and 
induction of ACC gene expression. In conclusion, EPA may modulate lipid metabolism by stimulation of lipolysis, which likely is mediated by induction of lipolytic gene expression and suppression of adipogenic gene expression in adipocytes.

Acknowledgments This work was supported by the Korea Science and Engineering Foundation (KOSEF) grant funded by the Korea government (MOST) (no. M10510130005-07N1013-00510).

\section{References}

1. Spiegelman BM, Flier JS (1996) Adipogenesis and obesity: rounding out the big picture. Cell 87:377-389

2. Kopelman PG (2000) Obesity as a medical problem. Nature 404:635-643

3. Visscher TL (2001) The public health impact of obesity. Annu rev public health 22:355-375

4. Hainault I, Carlotti M, Hajduch E, Guichard C, Lavau M (1993) Fish oil in a high lard diet prevents obesity, hyperlipidemia, and adipocyte insulin resistance in rats. Annu N Y Acad Sci 683:98101

5. Parrish CC, Pathy DA, Angel A (1990) Dietary fish oils limit adipose tissue hypertrophy in rats. Metabolism 39:217-219

6. Davidson MH (2006) Mechanisms for the hypotriglyceridemic effect of marine omega-3 fatty acids. Am J Cardiol 98:27-33

7. Jump DB (2002) The biochemistry of $n-3$ polyunsaturated fatty acids. J Biol Chem 277:8755-8758

8. Moreno-Aliaga MJ, Matsumura F (1999) Endrin inhibits adipocyte differentiation by selectively altering expression pattern of
CCAAT/enhancer binding protein-alpha in 3T3-L1 cells. Mol Pharmacol 56:91-101

9. Rozen S and Skaletsky HJ (1998) Primer3. Code available at http://www-/genome.wi.mit.edu/genome_software/otherprimer3. html

10. Bravo E, Napolitano M, Lopez-Soldado I, Valeri M, Botham KM, Stefanutti C (2006) Hypercholesterolaemia alters the responses of the plasma lipid profile and inflammatory markers to supplementation of the diet with n-3 polyunsaturated fatty acids from fish oil. Eur J Clin Invest 36:788-795

11. Peyron-Caso E, Quignard-Boulang A, Laromiguiere M, FeingKwon-Chan S, Veronese A, Ardoun B, Slama G, Rixkalla SW (2003) Dietary fish oil increases lipid mobilization but does not decrease lipid storage-related enzyme activities in adipose tissue of insulin-resistant, sucrose-fed rats. J Nutr 133:2239-2243

12. McGarry JD, Foster DW (1980) Regulation of hepatic fatty acid oxidation and ketone body production. Annu Rev Biochem 49:395-420

13. McGarry JD, Brown NF (1997) The mitochondrial carnitine palmitoyltransferase system: from concept to molecular analysis. Eur J Biochem 244:1-14

14. Rousseau V, Becker DJ, Ongemba LN, Rahier J, Henquin JC, Brichard SM (1997) Developmental and nutritional changes of ob and PPAR gamma 2 gene expression in rat white adipose tissue. Biochem J 321:451-456

15. Schoonjans K, Staels B, Auwerx J (1996) The peroxisome proliferator activated receptors (PPARs) and their effects on lipid metabolism and adipocyte differentiation. Biochim Biophys Acta 1302:93-109

16. Kim KH (1997) Regulation of mammalian acetyl-coenzyme A carboxylase. Annu Rev Nutr 17:77-99

17. Wakil SJ, Stoops JK, Joshi VC (1983) Fatty acid synthesis and its regulation. Annu Rev Biochem 52:537-579 